\title{
URGENSI PEMBARUAN SISTEM HUKUM EKONOMI INDONESIA BERDASARKAN NILAI-NILAI PANCASILA
}

\author{
Maryanto \\ Fakultas Hukum Universitas Islam Sultan Agung Semarang \\ E-mail : maryanto@unissula.ac.id
}

\begin{abstract}
The developing of economic law in this time, give substantial impact for the fairness of Indonesian society. The fairness is expected start from making regulation, implementation by official enforcement, legal culture then supported with good infrastructure and supported with society, seems haven't distribute equally and proportionaly. This is because the values of Pancasila that eroded with economical interest of business and political interest of ruler so much act that made judicial reviewed that corrected one or some even acts that canceled by Mahkamah Konstitusi. Therefore, the values of Pancasila should be guidlines to making policy or political policy of Indonesian economic law, and should synergetic of making regulations, implementations by official enforcement, legal culture that supported with good infrastructure and supporting from society in order to create Indonesian economic of law according values of Pancasila according to state goals.
\end{abstract}

Keywords : renewal, system, economic, law, Pancasila.

\begin{abstract}
Abstrak
Perkembangan hukum ekonomi masa ini membawa dampak secara substansial bagi keadilan masyarakat Indonesia. Keadilan yang diharapkan mulai dari pembuatan regulasi, implementasi oleh aparat penegak hukum, budaya hukum kemudian didukung dengan sarana prasarana yang baik dan didukung pula oleh masyarakat, nampaknya belum terdistribusi secara merata dan proporsional. Hal ini disebabkan karena nilai-nilai Pancasila yang mulai terkikis dengan kepentingan ekonomi para pengusaha dan kepentingan politik penguasa sehingga banyak undang-undang yang terbentuk mengalami judicial review yang dikoreksi salah satu atau beberapa pasal bahkan undang-undang yang dibatalkan oleh Mahkamah Konstitusi. Maka dari itu nilai-nilai Pancasila hendaknya menjadi pedoman dalam penyusunan arah kebijakan atau politik hukum ekonomi Indonesia, dan hendaknya ada sinergitas dalam penyusunan regulasi, implementasi oleh aparat penegak hukum, budaya hukum yang ditopang dengan sarana prasarana yang baik dan dukungan masyarakat agar tercipta hukum ekonomi Indonesia yang berdasarkan nilai-nilai Pancasila sesuai tujuan negara.
\end{abstract}

Kata kunci: pembaharuan, sistem, hukum, ekonomi, Pancasila. 


\section{A. Pendahuluan}

Perjalanan hukum dalam kehidupan masyarakat sejak 1945 sampai Indonesia merdeka senantiasa dihadapkan pada berbagai masalah yang semakin lama semakin kompleks terutama di bidang ekonomi. Arus globalisasi yang demikian derasnya membawa dampak negatif dan positif yang apabila dicermati lebih banyak membawa dampak negatifnya bagi Indonesia. Misalkan dalam hal perdagangan, produk Cina yang masuk ke Jawa Tengah tahun 2015 ini mencapai 41 persen dari total impor produk yang masuk ke Jawa Tengah. Bahkan Indonesia mengalami defisit perdagangan sekitar US\$ 26-27 miliar (Koran Tempo, 5 Juni 2015). Tidak hanya itu, permasalahan dalam perizinan, perizinan eksplorasi dan eksploitasi minyak dan gas bumi terdapat sekitar 289 perizinan di pusat dan daerah yang dinilai tumpang tindih (Koran Tempo, 13 Oktober 2014).

Banyaknya Undang-Undang (UU) yang di-judicial review oleh Mahkamah Konstitusi (MK) yang membatalkan, mengoreksi satu, beberapa sampai seluruh pasal dalam undang-undang, khususnya undang-undang bidang ekonomi membuat publik mempertanyakan kualitas undang-undang yang dibuat oleh DPR bersama Pemerintah. Disamping itu terlihat ketidakberpihakan legislatif dan eksekutif dalam membuat kebijakan (UU) yang tidak pro kepada rakyat.

UU bidang perekonomian yang memberikan landasan bagi para pelaku ekonomi yang banyak mengakomodasi kepentingan pasar dengan memberikan kepastian hukum bagi perputaran barang dan/atau jasa telah memberikan kesenjangan ekonomi bagi sebagian besar masyarakat. Tidak hanya itu, faktor politik dan hukum yang saling mendeterminasi juga ikut mendorong hukum dan sistem hukum tereduksi oleh tarikan kepentingan pengusaha (pasar), kepentingan penguasa, dan kepentingan rakyat. Seperti dikatakan John Gilissen dan Frits Gorlé, dengan peranan hukum, kelompok-kelompok masyarakat dapat menikmati posisi ekonomi yang memadai dan dapat pula kelompokkelompok masyarakat tersebut mengalami penindasan dan tergencet oleh kekuatan politik (John Gilissen dan Frits Gorlé, 2005: 97).

Korelasi antara hukum dan ekonomi yang demikian erat dan saling mempengaruhi untuk memenuhi berbagai kebutuhan manusia dalam pergaulan hidupnya dimana perkembangan ekonomi akan mempengaruhi peta hukum. Demikian pula sebaliknya, perubahan hukum akan memberikan dampak yang luas terhadap ekonomi (Johannes Ibrahim dan Lindawaty Sewu, 2007: 45).

Kekayaan alam Indonesia yang melimpah nampaknya belum dapat diwujudkan oleh negara sebagai salah satu tujuan negara yakni untuk mencapai kesejahteraan umum sebagaimana diamanatkan pada Pembukaan UUD 1945 alinea IV. Pasal 33 ayat (3) UUD 1945 telah dengan jelas menyebutkan bahwa bumi air dan kekayaan alam yang terkandung di dalamnya dikuasai oleh negara dan dipergunakan untuk sebesar-besar kemakmuran rakyat. Kata kemakmuran rakyat yang hendak dituju ini belum tercapai secara optimal karena pembangunan hukum ekonomi saat ini tidak berlandaskan pada nilai-nilai Pancasila. Teguh Prasetyo mengatakan, sistem hukum yang dilandasi dan dipedomani serta dijiwai oleh bilai-nilai falsafah Pancasila bertujuan agar sistem hukum 
di Indonesia lebih baik di kemudian hari sehingga mampu memuskan semua pihak, karena sistem hukum berdasarkan Pancasila bersifat terbuka yang mampu menampung aspirasi yang tumbuh dan berkembang di dunia internasional karena adanya pengaruh globalisasi, juga harus bersifat adaptif yaitu dapat menyesuaikan diri dengan kepribadian bangsa Indonesia (Teguh Prasetyo, 2013: 113).

Kepribadian bangsa Indonesia yang demikian ini karena bangsa Indonesia sebagai manifestasi nation state yang berperadaban merupakan wujud potret negara majemuk telah menghimpun deklarasi bernegara dalam konteks Pancasila sebagai norma dasar (staats fundamnetalnorm). Pancasila oleh para pendiri bangsa (founding fathers) merupakan pengejawantahan dari karakteristik masyarakat dan budaya bangsa secara materiil (Ria Casmi Arrsa, 2011: 36). Pancasila sebagai akar dari cita hukum bangsa Indonesia memberikan konsekuensi bahwa dalam dinamika kehidupan berbangsa dan bernegara, sebagai pandangan hidup yang dianut akan memberikan koherensi dan direksi (arah) pada pikiran dan tindakan. Cita hukum adalah gagasan, karsa, cipta dan pikiran berkenaan dengan hukum atau persepsi tentang makna hukum, yang dalam intinya terdiri atas tiga unsur yakni keadilan, kehasilgunaan dan kepastian hukum. Cita hukum terbentuk dalam pikiran dan sanubari manusia sebagai produk berpadunya pandangan hidup, keyakinan keagaamaan dan kenyataan kemasyarakatan. Sejalan dengan itu maka, Ilmu hukum dan hukum Indonesia seyogyanya bertumpu dan mengacu pada cita hukum tersebut (B. Arief Sidharta, 2010 : 84-85).

Menurut Tim Harford, di satu pihak kita harus menghindari inefisiensi, tetapi di pihak lain kita juga harus menjamin agar kekayaan tersebar secara adil dan merata. Kita membutuhkan jalan untuk mengembangkan agar perekonomian kita efisien, tetapi juga berkeadilan (Jimly Asshiddiqie, 2010: 259).

Sistem hukum yang dimaksud sebagaimana yang dikemukakan oleh Soerjono Soekanto bahwa suatu sistem hukum itu akan berjalan dengan baik apabila unsur-unsur sistem hukum yang meliputi undang-undang (substansi hukum), aparat penegak hukum, sarana prasarana (infrastruktur), masyarakat, dan budaya berjalan dengan baik. Adapun Pancasila sebagai sumber dari segala sumber hukum menjadi pondasi utama dalam menyelaraskan unsur-unsur tersebut sesuai dan berujung pada tujuan dari negara. Berdasarkan uraian-uraian di atas dapat dikemukakan beberapa permasalahan yakni: 1. Apakah urgensi pembaruan sistem hukum ekonomi berdasarkan nilai-nilai Pancasila? 2. Bagaimana melakukan pembaruan sistem hukum ekonomi berdasarkan nilai-nilai Pancasila?

\section{B. Pancasila sebagai Pedoman Dasar Pembaruan Hukum Ekonomi Indonesia}

Di era globalisasi seperti saat ini telah menjadikan dunia seolah tanpa batas, sekat antara negara satu dengan yang lainnya menjadi maya (borderless state). Hal yang demikian terjadi karena perkembangan teknologi komunikasi yang semakin canggih dan akibat selanjutnya adalah dunia akan dikuasai oleh mereka yang mampu menguasai teknologi informasi. Hegemoni oleh suatu negara terhadap negara lain pada era globalisasi ini tidak melulu melalui penguasaan fisik dengan cara pendudukan (okupasi) 
belaka namun dapat melalui dunia maya, yang dengan demikian imperialisme telah mengalami perubahan bentuk dari yang fisik menjadi yang maya/non fisik.

Akibat yang lebih jauh dari imperialisme di era globalisasi ini adalah semakin terpinggirkannya/hilangnya jati diri suatu bangsa termasuk bangsa Indonesia, dan digantikan oleh paham/ideologi yang memenangi pertarungan tersebut dalam hal ini adalah ideologi liberalisme. Ideologi liberal ini sejatinya sudah sejak dari dulu menguasai bangsa kita, tepatnya sejak era kolonialisme hingga saat ini. Hal yang demikian dapat kita lihat dari ketidakmampuan dan ketidakmauan bangsa kita untuk menggantikan hukum tinggalan kolonialisme yang berurat pada liberalisme dan sekulerisme kepada hukum yang dijiwai oleh nilai-nilai yang hidup dalam sanubari bangsa Indonesia yakni Pancasila. Konsep negara hukum Indonesia adalah konsep negara hukum Pancasila. Konsep negara hukum Pancasila merupakan konsep negara hukum yang prismatik, yaitu konsep negara hukum yang menggabungkan unsur-unsur negara hukum yang berbeda terutama unsur rechstaat dan unsur rule of law dengan dilandasi pada nilai-nilai Pancasila, yaitu Ketuhanan yang Maha Esa, kekeluargaan, gotong royong, dan kerukunan (Arie Purnomosidi, 2012: vi). Akan tetapi melihat hukum ekonomi kita nampaknya sistem hukum kita terasa kering dari nilai-nilai Ketuhanan yang Maha Esa, kekeluargaan, gotong royong, dan kerukunan.

Sebagaimana diketahui bahwa Pancasila sebagai dasar filsafat serta ideologi dan sumber dari segala sumber hukum bangsa dan negara Indonesia, bukan terbentuk secara mendadak serta bukan hanya diciptakan oleh perorangan sebagaimana yang terjadi pada ideologi-ideologi lain di dunia, namun terbentuknya Pancasila melalui proses yang cukup panjang dalam sejarah bangsa Indonesia. Secara kausalitas Pancasila sebelum disahkan menjadi dasar filsafat negara, nilai-nilainya telah ada dan berasal dari bangsa Indonesia sendiri yang berupa nilai-nilai adat istiadat, kebudayaan dan nilai-nilai religius. Kemudian para pendiri negara mengangkat nilai-nilai tersebut dan dirumuskan secara musyawarah mufakat berdasarkan moral yang luhur, antara lain dalam sidangsidang BPUPKI dan PPKI yang akhirnya pada tanggal 18 Agustus 1945 dinyatakan sah oleh PPKI sebagai dasar falsafah negara Republik Indonesia.

Bagi bangsa Indonesia, Pancasila mempunyai fungsi dan peranan yang bermacam-macam antara lain (M. Ali Mansyur, 2006 : 138-140) :

1. Pancasila sebagai Pandangan Hidup Bangsa.

Pancasila merupakan rangkaian nilai-nilai luhur, yang menyeluruh terhadap kehidupan itu sendiri yang berfungsi sebagai kerangka acuan baik untuk menata kehidupan diri pribadi maupun dalam berinteraksi antar manusia dalam masyarakat serta alam sekitarnya. Menjadikan Pancasila menjadi pandangan hidup, maka bangsa Indonesia akan mengetahui arah mana tujuan yang ingin dicapainya, akan mampu memandang dan memecahkan segala persoalan yang dihadapinya secara tepat, sehingga tidak teromabang-ambing dalam menghadapi persoalan tersebut, mengapa? Karena pancasila adalah merupakan kristalisasi dari nilai-nilai yang hidup dalam masyarakat Indonesia dan berakar pada budaya bangsa, maka akan dijunjung tinggi oleh warganya. 
Puncaknya Pancasila merupakan cita-cita moral bangsa yang memberikan pedoman dan kekuatan rokhaniah bagi bangsa Indonesia dalam kehidupan bermasyarakat, berbangsa dan bernegara.

2. Pancasila sebagai Dasar Negara Republik Indonesia.

Pancasila dalam kedudukan ini sering disebut sebagai dasar filsafat atau dasar falsafah negara (philosohische Gronslas) dari negara, ideologi negara (staatsidee). Dalam pengertian ini Pancasila merupakan suatu dasar nilai serta norma untuk mengatur pemerintahan negara/penyelenggaraan negara.

Konsekuensinya seluruh pelaksanaan dan penyelenggaraan negara terutama segala peraturan perundang-undangan negara dijabarkan dan diderivikasi dari nilainilai Pancasila. Karena itu Pancasila merupakan sumber dari segala sumber hukum.

Kedudukan Pancasila merupakan dasar negara Republik Indonesia tersimpul dalam pembukaan UUD 1945 alinea IV, Ketetapan MPRS No. XX/MPRS/1966 jo TAP No. V/MPR/1973 dan Ketetapan No. IX/MPR/1978.

3. Pancasila sebagai Ideologi Negara dan Bangsa Indonesia.

Pancasila sebagai ideologi bagi bangsa Indonesia pada hakekatnya bukan hanya merupakan suatu hasil perenungan atau pemikiran seseorang atau sekelompok orang sebagaimana ideologi lain, namun Pancasila diangkat dari pandangan masyarakat Indonesia sendiri, sehingga bangsa Indonesia merupakan causa materialis (bahan asal) Pancasila.

Ideologi adalah ajaran/doktrin/theori yang diyakini kebenarannya, yang disusun secara sistimatis, dan diberi petunjuk pelaksanaannya dalam menanggapi dan menyelesaikan masalah yang dihadapinya dalam bermasyarakat, berbangsa dan bernegara. Ideologi negara pada hakekatnya merupakan asas kerokhaniahan, merupakan sumber cita-cita, harapan nilai-nilai serta norma-norma yang dianggap baik, sehingga pancasila pada hakekatnya sebagai ideologi bertujuan mewujudkan kesejahteraan hidup bagi bangsa Indonesia. Ketentuan tentang ideologi Pancasila ini dapat ditemukan dalam pembukaan UUD 1945 alinea ke-4.

4. Pancasila sebagai Ideologi Terbuka.

Pancasila sebagai ideologi tidak bersifat kaku dan tertutup namun bersifat terbuka, aktual, dinamis, antisipatif dan senantiasa mampu menyesuaikan dengan perkembangan zaman, ilmu pengetahuan dan teknologi serta dinamika perkembangan masyarakat. Keterbukaan ideologi Pancasila bukan berarti mengubah nilai-nilai dasar yang terkandung didalamnya, namun mengekplisitkan wawasannya secara lebih kongkrit, sehingga memiliki kemampuan yang lebih tajam untuk memecahkan masalah-masalah baru dan aktual yang senantiasa berkembang seiring dengan tuntutan zaman.

Dalam aplikasinya ideologi Pancasila yang bersifat terbuka, dikenal ada 3 (tiga) tingkat nilai yaitu nilai dasar yang tidak berubah yaitu pembukaan UUD 1945 yang merupakan pencerminan dari Pancasila, kemudian nilai instrumental 
sebagai sarana mewujudkan nilai dasar yang senantiasa sesuai dengan keadaan. Nilai praktis yang berupa nilai pelaksanaan secara nyata yang sesungguhnya dalam kehidupan yaitu UU dan peraturan pelaksanaan lainnya, yang sewaktu-waktu dapat berubah seiring dengan derap perkembangan yang ada.

Seiring dengan itu sudah tentu kita harus pula mengikuti kosekuensi logis dengan keyakinan tersebut, bahwa segala sikap, perilaku, kebijakan dan peraturan dalam kehidupan bermasyarakat, berbangsa dan bernegara harus sebangun serta senafas dengan nilai-nilai Pancasila.

Di bidang hukum, Pancasila selama ini ditempatkan sebagai sumber dari segala sumber hukum hanyalah menjadi jargon belaka, belum sebangun serta senafas. Hal ini terjadi karena ketiadaan kerangka implementasi terhadap konsep tersebut. Sehubungan dengan hal tersebut Mahfudz MD mengintroduksi empat kaidah untuk penuntun dalam pembuatan politik hukum atau kebijakan negara lainnya agar Pancasila tidak sekedar menjadi jargon belaka yakni (M. Mahfudz MD, 2009 : 31-32) :

Pertama, kebijakan umum dan politik hukum harus tetap menjaga integrasi atau keutuhan bangsa baik secara ideologi maupun secara teritori. Setiap hukum atau kebijakan apapun di Indonesia tidak boleh menyebabkan terancamnya keutuhan kita sebagai bangsa baik ideologis maupun wilayah teritorinya. Politik hukum dan kebijakan umum haruslah menjadi milik dan diterima secara bersama tanpa dirusak oleh nilai-nilai sektarian. Haruslah ditangkal dan ditindak tegas setiap kebijakan atau upaya apapun yang berpotensi merobek keutuhan ideologi dan teritori kita.

Kedua, kebijakan umum dan politik hukum haruslah didasarkan pada upaya membangun demokrasi (kedaulatan rakyat) dan nomokrasi (negara hukum) sekaligus. Indonesia adalah negara demokrasi yang berarti menyerahkan pemerintahan dan penentuan arah kebijakan negara kepada rakyat melalui kontestasi politik yang sehat, namun Indonesia juga adalah negara hukum (nomokrasi) sehingga setiap kebijkan negara yang dibuat atas nama rakyat haruslah sesuai dengan prinsip-prinsip hukum dan dan filosofi hukum yang mendasarinya. Demokrasi biasanya mendasarkan diri pada pertarungan menang atau kalah, sedangkan nomokrasi mendasarkan diri pada masalah benar atau salah. Oleh karena itu keputusan-keputusan yang diambil secara demokratis tetapi isinya salah maka dapat dibatalkan oleh proses nomokratis (misalnya melalui judicial review) untuk membenarkannya.

Ketiga, Kebijakan umum dan politik hukum haruslah didasarkan pada upaya membangun keadilan sosial bagi seluruh rakyat Indonesia. Indonesia bukanlah penganut liberalisme, tetapi secara ideologis menganut prismatika antara individualisme dan kolektivisme dengan titik berat pada kesejahteraan umum dan sosial. Itulah sebabnya dalam pembangunan sosial dan ekonomi kita menganut ekonomi kerakyatan, kebersamaan, gotong royong dan toleransi sebagaimana ditegaskan prinsipnya di dalam Pasal 33 dan Pasal 34 UUD 1945. Keadilan sosial 
adalah keadilan yang diciptakan melalui penciptaan struktur-struktur yang adil oleh negara sehingga kesenjangan antara yang kuat dan yang lemah mengecil secara terus menerus.

Keempat, politik hukum haruslah didasarkan pada prinsip toleransi beragama yang berkeadaban. Indonesia bukan negara agama sehingga tidak boleh melahirkan kebijakan atau politik hukum yang berdasar atau dominasi oleh satu agama tertentu atas nama apapun; tetapi Indonesia juga bukan negara sekuler yang hampa agama sehingga setiap kebijakan atau politik hukumnya haruslah dijiwai ajaran berbagai agama-agama yang bertujuan mulia bagi kemanusiaan. Kedudukan agama sebagai sumber hukum haruslah diartikan sebagai sumber hukum materiil yakni bahan untuk dijadikan hukum formal atau peraturan perundang-undangan yang memiliki bentuk tertentu setelah diolah dengan bahan-bahan hukum yang lain. Seperti diketahui bahwa sumber hukum itu ada dua yakni materiil dan formil. Sumber hukum materiil adalah berbagai bahan yang diolah untuk dijadikan hukum formal. Sumber hukum formal adalah peraturan perundang-undangan yang dibentuk secara resmi oleh negara sebagai hasil pengolahan atas sumber hukum materiil. Sumber hukum formal dapat merupakan produk ekletisisme (percampuran dengan saling mengisi) dari berbagai sumber hukum materiil seperti agama, budaya, antropologi, adat, hukum asing yang kemudian lahir sebagai hukum nasional dan bukan lagi sebagai hukum agama atau hukum kelompok tertentu. Dengan demikian hukum agama atau hukum kelompok tertentu. Dengan demikian hukum agama tidak harus menjadi hukum sendiri dalam bentuk peraturan perundang-undangan melainkan cukup menjadi bahan materiil yang diekletiskan dengan bahan materiil lainnya. Dalam kaidah penuntun yang demikian negara tidak memberlakukan hukum agama, tetapi memberikan proteksi sepenuhnya bagi warga negara yang akan melaksanakan ajaran agama sesuai dengan keyakinannya.

Politik hukum Indonesia tercermin dalam UU No 17 Tahun 2007 tentang Rencana Pembangunan Jangka Panjang Nasional Tahun 2005-2025 (UU RPJPN), mengamanatkan visi dan misi pembangunan nasional tahun 2005-2025 adalah Indonesia yang Mandiri, Maju, Adil dan Makmur. Adapun ukuran kemandirian menurut UU RPJPN tersebut antara lain:

1. ketersediaan sumber daya manusia yang berkualitas dan mampu memenuhi tuntutan kebutuhan dan kemajuan pembangunan;

2. kemandirian aparatur pemerintah dan aparatur penegak hukum dalam menjalankan tugasnya;

3. kemampuan membiayai pembangunan melalui sumber keuangan dalam negeri, dan memperkecil ketergantungan dari luar negeri;

4. kemampuan memenuhi sendiri kebutuhan pokok.

UU RPJPN memberikan ukuran kemajuan sebagai berikut:

1. indikator kependudukan seperti laju pertumbuhan penduduk, kesehatan; 
2. kualitas pelayanan sosial;

3. tingginya produktivitas penduduk;

4. tingkat pendapatan dan pembagiannya;

5. perekonomian yang stabil;

6. kelembagaan politik dan kemasyarakatan yang berfungsi dengan baik.

Kemudian UU RPJPN memberikan ukuran kemakmuran suatu bangsa sebagai bangsa yang sudah terpenuhi seluruh kebutuhan hidupnya, sehingga dapat memberikan makna dan arti penting bagi bangsa-bangsa lain di dunia. Visi Indonesia tersebut merupakan ekstraksi dari tujuan negara Indonesia, maka dari itu dalam UU tersebut, dalam mewujudkan visi pembangunan nasional ditempuh 8 (delapan) misi pembangunan nasional sebagai berikut :

1. mewujudkan masyarakat yang berakhlak mulia, bermoral, beretika, berbudaya, dan beradab berdasarkan falsafah Pancasila;

2. mewujudkan bangsa yang berdaya saing;

3. mewujudkan masyarakat yang demokratis berdasarkan hukum;

4. mewujudkan Inodnesia aman, damai, dan bersatu;

5. mewujudkan pemerataan pembangunan dan berkedilan;

6. mewujudkan Indonesia asri dan lestari;

7. mewujudkan Indonesia menjadi negara kepuluan yang mandiri, maju, kuat, dan berbasiskan kepentingan nasional; dan

8. mewujudkan Indonesia berperan penting dalam pergaulan dunia internasional.

\section{Pancasila sebagai Dasar Pembaruan Sistem Hukum Ekonomi Indonesia}

Menurut Shorde dan Voich sebagaimana dikutip oleh Satjipto Rahardjo, sistem mempunyai dua pengertian, pertama, pengertian sistem jenis satuan yang mempunyai tatanan tertentu. Tatanan disini menunjuk kepada pranata struktur yang tersusun dari bagian-bagian. Kedua, sistem sebagai suatu rencana, metode atau prosedur untuk mengerjakan sesuatu (Satjipto Rahardjo, 2000: 48).

Didalam suatu sistem terkandung beberapa hal (Satjipto Rahardjo, 2000: 48-49):

1. Sistem itu berorientasi pada tujuan.

2. Keseluruhannya adalah lebih dari sekedar jumlah dari bagian-bagiannya (wholism).

3. Suatu sistem berinteraksi dengan sistem yang lebih besar, yaitu lingkungan (keterbukaan sistem).

4. Bekerjanya bagian-bagian dari sistem itu menciptakan sesuatu yang berharga (tranformasi).

5. Masing-masing bagian harus cocok satu sama lain (keterhubungan).

6. Ada kekuatan pemersatu yang mengikat sistem itu (mekanisme kontrol).

Nilai-nilai Pancasila sebagai sumber dari segala sumber hukum yang terdiri dari Ketuhanan yang Maha Esa, kekeluargaan, gotong royong, dan kerukunan harus ada dalam setiap unsur sistem hukum ekonomi Indonesia. Hal ini menjadi penting dikarenakan nilai Pancasila yang diterapkan ke dalam sistem hukum ekonomi 
menyebabkan apa yang menjadi tugas dari hukum di dalam masyarakat, das sein sesuai dengan das sollen. Apa yang dicita-citakan oleh hukum yaitu kemakmuran dan pemerataan keadilan dapat tercapai, sengketa apa pun yang diselesaikan dengan berlandaskan nilai-nilai Pancasila dapat tercapai apa yang dinamakan musyawarah mufakat dan win-win solution. Berikut dipaparkan implementasi nilai-nilai Pancasila dalam sistem hukum ekonomi :

1. Substansi hukum ekonomi yang berdasarkan Pancasila.

Pasal 2 UU No 12 Tahun 2011 tentang Pembentukan Peraturan Perundangundangan menyebutkan bahwa Pancasila merupakan sumber segala sumber hukum negara. Pada penjelasan pasal tersebut, penempatan Pancasila sebagai sumber dari segala sumber hukum negara adalah sesuai dengan Pembukaan UUD 1945 alinea IV. Kemudian menempatkan Pancasila sebagai dasar dan ideologi negara serta sekaligus dasar filosofis negara sehingga setiap materi muatan Peraturan Perundang-undangan tidak boleh bertentangan dengan nilai-nilai Pancasila.

Peraturan-perundang-undangan yang dibentuk oleh legislatif dan eksekutif hendaknya mengakomodasi kepentingan rakyat dan sesuai dengan amanat konstitusi (UUD 1945). Peraturan perundang-undangan yang tidak mengakomodasi kepentingan rakyat dan tidak sesuai dengan konstitusi akan di-judicial review melalui MK maupun MA (jika peraturan tersebut di bawah undang-undang). Misalkan UU di bidang ekonomi banyak yang dikoreksi/dibatalkan oleh MK sehingga dapat disimpulkan bahwa dalam hal pembuatan UU tidak mengakomodasi kepentingan rakyat sebagaimana tertuang dalam konstitusi tetapi masih mengakomodasi kepentingan pengusaha (pasar) yang tidak sesuai dengan normanorma yang terkandung dalam konstitusi. Adi Sulistiyono mencatat setidaknya ada 15 (lima belas) Putusan MK yang men-judicial review undang-undang di bidang ekonomi, diantaranya (Adi Sulistiyono, 2014: 25) :

Tabel 1. Putusan MK dan UU yang Di-judicial review

\begin{tabular}{|c|c|c|}
\hline No & Putusan MK & UU yang di-judicial review \\
\hline 1. & Putusan MK No 64/PUU-X/2012 & $\begin{array}{l}\text { UU No } 10 \text { Tahun } 1998 \text { tentang } \\
\text { Perubahan Atas UU No } 7 \text { Tahun } 1992 \\
\text { tentang Perbankan }\end{array}$ \\
\hline 2. & $\begin{array}{l}\text { Putusan MK No 002/PUU-I/2003 dan } \\
\text { Putusan MK No 36/PUU-X/2012 }\end{array}$ & $\begin{array}{l}\text { UU No } 22 \text { Tahun } 2001 \text { tentang } \\
\text { Minyak dan Gas Bumi }\end{array}$ \\
\hline 3. & $\begin{array}{l}\begin{array}{l}\text { Putusan } \\
\text { I/2003 }\end{array} \\
\end{array}$ & $\begin{array}{l}\text { UU No } 20 \text { Tahun } 2002 \text { tentang } \\
\text { Ketenagalistrikan }\end{array}$ \\
\hline 4. & Putusan MK No 005/PUU-I/2003 & $\begin{array}{l}\text { UU No } 32 \text { Tahun } 2002 \text { tentang } \\
\text { Penyiaran }\end{array}$ \\
\hline 5. & Putusan MK No 071/PUUII/2004 & $\begin{array}{l}\text { UU No } 37 \text { Tahun } 2004 \text { tentang } \\
\text { Kepailitan dan Penundaan Kewajiban } \\
\text { Pembayaran Utang }\end{array}$ \\
\hline 6. & Putusan MK No 21-22/PUU-V/2007 & $\begin{array}{l}\text { UU No } 25 \text { Tahun } 2007 \text { tentang } \\
\text { Penanaman Modal }\end{array}$ \\
\hline 7. & Putusan MK No 93/PUU-X/2012 & $\begin{array}{l}\text { UU No } 21 \text { Tahun } 2008 \text { tentang } \\
\text { Perbankan Syariah }\end{array}$ \\
\hline
\end{tabular}




\begin{tabular}{|l|l|l|}
\hline 8. & $\begin{array}{l}\text { Putusan MK No 10/PUU-X/2012 } \\
\text { Putusan MK No 25/PUU-VIII/2010 } \\
\text { Putusan MK No 30/PUU-VII/2010 } \\
\text { Putusan MK No 32/PUU-VIII/2010 }\end{array}$ & $\begin{array}{l}\text { UU No 4 Tahun 2009 tentang } \\
\text { Pertambangan Mineral dan Batubara }\end{array}$ \\
\hline 9. & Putusan MK No 38/PUU-XI/2013 & $\begin{array}{l}\text { UU No 44 Tahun } 2009 \text { tentang Rumah } \\
\text { Sakit }\end{array}$ \\
\hline 10. & Putusan MK No 14/PUU-X/2012 & $\begin{array}{l}\text { UU No 1 Tahun 2011 tentang } \\
\text { Perumahan dan Kawasan Pemukiman }\end{array}$ \\
\hline 11. & Putusan MK No 28/PUU-XI/2013 & $\begin{array}{l}\text { UU No 17 Tahun 2012 tentang } \\
\text { Perkoperasian }\end{array}$ \\
\hline
\end{tabular}

Di samping itu, putusan-putusan pengadilan yang dibuat oleh hakim dalam sengketa perdata hendaknya lebih mengedepankan sisi keadilan para pihak dengan melihat ada atau tidaknya moral hazard para pihak melalui track record para penggugat-tergugat maupun kuasa hukumnya. Hal tersebut patut dilakukan disamping pada pokoknya melihat bukti formil yang diajukan oleh para pihak.

2. Struktur hukum ekonomi yang berdasarkan Pancasila

Struktur diibaratkan sebagai subyek/pelaku penegak hukum dimana dalam hal ini adalah aparat pemerintah (legislatif) pusat hingga di level daerah. Kemudian jajaran kementerian, lembaga yang setingkat dengan kementerian hingga level dinas di daerah. Sinergitas yang terjalin dalam pelayanan di bidang perizinan yang terpadu, pengetatan sanksi berupa denda, pencabutan izin usaha supaya memberikan efek jera, penerapan sistim on line guna memutus rantai kolusi, korupsi dan nepotisme, penambahan dan penguatan SDM melalui pelatihanpelatihan dan studi lanjut akan membawa perubahan ke arah yang lebih baik dengan disertai rasa gotong royong membawa semangat beribadah dalam bekerjanya aparat penegak hukum.

Apabila dilihat dari sisi penyelenggaraan daerah misalkan, nampak bahwa tata pemerintahan daerah di Indonesia kurang bisa disatukan. Hal ini terbukti dengan banyaknya daerah yang mengalami pembentukan, dan pemekaran sehingga dapat dibayangkan, berapa triliun uang yang digunakan untuk menyelenggarakan pemilu kepada daerah dan legislatifnya. Padahal, hukum ekonomi yang baik itu disamping mampu mewujudkan efisiensi yang berkeadilan dan efektivitas, juga harus mampu menjadi sarana untuk mendistribusikan keadilan. Disamping itu alangkah baiknya jika upaya pemekaran tersebut ditiadakan dengan menyederhanakan/penggabungan daerah kabupaten/kota. Hal ini guna menghindari pemecahan-pemecahan yang menjadikan raja-raja kecil di daerah yang tidak menciptakan persatuan dan kesatuan (kerukunan dan gotong-royong) sehingga hanya menjadikan Pancasila sebagai jargon semata. 
Jumlah provinsi, kabupaten/kota di Indonesia dapat dilihat pada tabel berikut (http://otda.kemendagri.go.id/images/file/new_data/daftar\%20jumlah\%20prov.pdf):

Tabel 2. Jumlah Provinsi, Kabupaten/Kota di Indonesia

\begin{tabular}{|c|c|c|c|c|}
\hline \multirow{2}{*}{ No. } & \multirow{2}{*}{ Provinsi } & \multicolumn{3}{|c|}{ Jumlah } \\
\hline & & Kabupaten & Kota & Total \\
\hline 1. & Nanggroe Aceh Darussalam & 18 & 5 & 23 \\
\hline 2. & Sumatera Utara & 25 & 8 & 33 \\
\hline 3. & Sumatera Barat & 12 & 7 & 19 \\
\hline 4. & Riau & 10 & 2 & 12 \\
\hline 5. & Jambi & 9 & 2 & 11 \\
\hline 6. & Sumatera Selatan & 12 & 4 & 16 \\
\hline 7. & Bengkulu & 9 & 1 & 10 \\
\hline 8. & Lampung & 13 & 2 & 15 \\
\hline 9. & Kepulauan Bangka Belitung & 6 & 1 & 7 \\
\hline 10. & Kepulauan Riau & 5 & 2 & 7 \\
\hline 11. & Daerah Khusus Ibukota Jakarta & 1 & 5 & 6 \\
\hline 12. & Jawa Barat & 18 & 9 & 27 \\
\hline 13. & Jawa Tengah & 29 & 6 & 35 \\
\hline 14. & Banten & 4 & 4 & 8 \\
\hline 15. & Jawa Timur & 29 & 9 & 38 \\
\hline 16. & Yogyakarta & 4 & 1 & 5 \\
\hline 17. & Bali & 8 & 1 & 9 \\
\hline 18. & Nusa Tenggara Barat & 8 & 2 & 10 \\
\hline 19. & Nusa Tenggara Timur & 21 & 1 & 22 \\
\hline 20. & Kalimantan Barat & 12 & 2 & 14 \\
\hline 21. & Kalimantan Tengah & 13 & 1 & 14 \\
\hline 22. & Kalimantan Selatan & 11 & 2 & 13 \\
\hline 23. & Kalimantan Timur & 7 & 3 & 10 \\
\hline 24. & Sulawesi Utara & 11 & 4 & 15 \\
\hline 25. & Sulawesi Tengah & 11 & 1 & 12 \\
\hline 26. & Sulawesi Selatan & 21 & 3 & 24 \\
\hline 27. & Sulawesi Tenggara & 11 & 2 & 13 \\
\hline 28. & Gorontalo & 5 & 1 & 6 \\
\hline 29. & Sulawesi Barat & 6 & - & 6 \\
\hline 30. & Maluku & 9 & 2 & 11 \\
\hline 31. & Maluku Utara & 8 & 2 & 10 \\
\hline 32. & Papua & 28 & 1 & 29 \\
\hline 33. & Papua Barat & 12 & 1 & 13 \\
\hline 34. & Kalimantan Utara & 4 & 1 & 5 \\
\hline Tota & Kabupaten/Kota & 410 & 98 & 508 \\
\hline Juml & ah Provinsi, Kabupaten dan Kota & & & 542 \\
\hline
\end{tabular}

3. Membangun kultur hukum ekonomi yang berdasarkan Pancasila.

Kultur atau budaya merupakan suatu perilaku oleh anggota-anggota masyarakat yang secara akumulatif bertindak sesuai dengan cipta, rasa, dan karsa 
mereka. Berkaitan dengan hukum, apa yang nampak pada pikiran mereka yang dianggap sebagai kebenaran yang diimplementasikan dalam perilaku sehari-hari juga selaras dengan apa yang diinginkan oleh hukum. Dalam hal ekonomi, terciptanya pemerataan kesejahteraan sebagai akibat dari rasa Ketuhanan Yang Maha Esa, kerukunan, dan gotong royong yang merupakan nilai-nilai dari Pancasila

4. Sarana prasarana (infrastruktur) pendukung.

Apabila dicermati, potensi Indonesia luar biasa beragam, tetapi tidak didukung dengan sarana prasarana dan dikelola dengan baik. Menurut Soerjono Soekanto, tanpa adanya sarana atau fasilitas tertentu, maka tidak mungkin penegakan hukum akan berlangsung dengan lancar (Soerjono Soekanto, 2010: 37). Negara Indonesia yang berbentuk kepulauan dengan lebih dari 13.000 pulau menjadikan Indonesia negara kepulaun terbesar yang sampai sekarang masih belum tercipta pemerataan distribusi pembangunan kepada semua masyarakat. Maka dari itu, kesenjangan ekonomi yang tinggi yang dialami terutama oleh masyarakat yang berada di daerah terpencil dan terluar Indonesia serta masyarakat di Indonesia Bagian Timur sampai saat ini belum mendapat sarana prasarana (infrastruktur) pendukung yang baik sehingga pengadaan, perawatan dan pengelolaannya menjadi hal yang urgen ada sebagai solusi atas permasalahan tersebut.

Disamping itu pembangunan masih berfokus di pulau Jawa sehingga distribusi bahan-bahan pokok termasuk harga energi di luar Pulau Jawa menjadi sangat mahal. Misalkan di Jawa Barat sekitar Rp 4.250 per liter dibandingkan dengan harga Beras di Kabupaten Paniai Papua sebesar Rp. 18.000-an per liter (Koran Tempo, 24 April 2013). Harga premium saat ini di Jawa Rp 7.400 per liter. Di Papua bisa sampai ratusan ribu rupiah. Bahkan harga semen 1 (satu) sak bisa mencapai jutaan rupiah. Oleh karena itu, pembaruan atau pengadaan, perawatan sarana prasarana dan infrastruktur menjadi hal yang mendesak dilakukan oleh Pemerintah Pusat dan daerah, serta melibatkan peran swasta untuk membantu tercapainya tujuan negara.

5. Masyarakat Indonesia yang Pancasilais.

Masyarakat kini tidak menjadi obyek dari hukum yang dikenai perubahan semata. Pada masa ini masyarakat juga berhak menjadi para pembuat hukum. Pola pemberian perintah up-down dari kalangan penguasa untuk mengatur masyarakat, terutama masyarakat awam dan masyarakat bisnis berlaku pula mekanisme bottomup dimana ada upaya dari masyarakat untuk mengendaki seperti apa yang mereka inginkan menjadi hukum bagi mereka.

Mekanisme subsidi (migas, listrik, pupuk, dan sebagainya) yang masyarakat nikmati sehari-hari merupakan hal yang diinginkan oleh masyarakat karena dapat menekan selisih (split) harga pasar sehingga mereka mendapatkan keuntungan secara optimal. Melalui penciptaan kepastian hukum secara substansi, pemberlakuannya struktur hukum yang bersih dan berwibawa, kultur yang terbentuk kemudian ditopang dengan sarana prasarana yang kokoh dan merata, 
akan menciptakan masyarakat yang rukun, berlandaskan ketuhanan, dan gotong royong yang selaras dengan nilai-nilai Pancasila secara kopntinyu.

\section{Simpulan}

Berdasarkan paparan diatas dapat disimpulkan: 1. Urgensi pembaruan sistem hukum ekonomi berdasarkan nilai-nilai Pancasila adalah karena Indonesia merupakan negara yang kaya akan potensi sumber daya alam dan sumber daya manusia yang majemuk sehingga penambahan nilai-nilai Pancasila dalam sistem hukum ekonomi kita dapat memberikan penguatan sistem hukum ekonomi yang berdasarkan pada nilai-nilai ketuhanan, kerukunan, dan gotong royong dalam menjalankan aktivitas ekonomi. 2. Upaya melakukan pembaruan sistem hukum ekonomi berdasarkan nilai-nilai Pancasila dilakukan dengan memperhatikan politik hukum ekonomi melalui lima unsur sistem hukum ekonomi yaitu melalui substansi hukum, struktur hukum, kultur hukum, saranaprasarana (infrastruktur), dan masyarakat sehingga nilai-nilai Pancasila tidak hanya menjadi suatu jargon dan kesejahteraan tidak hanya menjadi mitos, tetapi dapat tercapai sesuai dengan tujuan negara. 


\section{DAFTAR PUSTAKA}

Adi Sulistiyono. "Prospek Pembaharuan Hukum yang Mendukung Iklim Usaha yang Kondusif”. Makalah pada acara Seminar Pengkajian Hukum Nasional (SPHN) 2014 dengan tema Prospek Pembaruan Hukum Pemerintahan Joko Widodo dan Muhammad Jusuf Kalla Periode Tahun 2014-2019 diselenggarakan Komisi Hukum Nasional, 2-3 Desember 2014 di Hotel Bidakara, Jakarta.

Arie Purnomosidi. 2012. Negara Hukum Pancasila (Analisis Terhadap UndangUndang Dasar 1945 Pra dan Pasca Amandemen). Tesis. Program Studi Magister Ilmu Hukum Program Pascasarjana Universitas Kristen Satya Wacana Salatiga.

B. Arief Sidharta. 2010. Ilmu Hukum Indonesia. Bandung: FH Unika Parahyangan.

http://otda.kemendagri.go.id/images/file/new_data/daftar\%20jumlah\%20prov.pdf. Diakses dari Direktorat Jenderal Otonomi Daerah Kementerian Dalam Negeri Republik Indonesia.

Jimly Asshiddiqie. 2010. Konstitusi Ekonomi. Jakarta : Kompas.

Johannes Ibrahim dan Lindawaty Sewu. 2007. Hukum Bisnis dalam Persepsi Manusia Modern. Cetakan ke-2. Bandung: Refika Aditama.

John Gilissen dan Frits Gorlé. 2005. Sejarah Hukum: Suatu Pengantar. Bandung: Refika Aditama. Terjemahan dari John Gilissen dan Frits Gorlé. 1991. Historische Inleiding tot het Recht. Anwerpent : Kluwer Rechtswetenschappen.

Koran Tempo. “Proyek MP3EI Tak Mampu Tekan Biaya Tinggi”. 24 April 2013.

Koran Tempo. “220 Izin Eksplorasi Akan Dipangkas.” 13 Oktober 2014.

Koran Tempo. “Dominasi Impor Produk Cina Ancam Perekonomian Jawa Tengah”. 5 Juni 2015.

M. Ali Mansyur. 2006. Aneka Persoalan Hukum, Semarang: Sultan Agung Press.

M. Mahfudz MD. 2009. Pancasila sebagai Hasil Karya dan Milik Bersama, Dalam konggres Pancasila 2009. Jakarta: Sekjen dan Kepaniteraan MK.

Ria Casmi Arrsa. 2011. Deideologi Pancasila (Analisis Kritis Perspektif Sejarah Hukum Ketatanegaraan Indonesia). Malang: Universitas Brawijaya Press (UB Press).

Satjipto Rahardjo. 2000. Ilmu Hukum. Cetakan ke-5. Bandung: Citra Aditya Bakti.

Soerjono Soekanto. 2012. Faktor-Faktor yang Mempengaruhi Penegakan Hukum. Cetakan ke-11. Jakarta: RajaGrafindo Persada.

Teguh Prasetyo. 2013. Hukum dan Sistem Hukum Berdasarkan Pancasila. Yogyakarta: Media Perkasa.

UUD 1945. 
UU No 17 Tahun 2007 tentang Rencana Pembangunan Jangka Panjang Nasional Tahun 2005-2025.

UU No 12 Tahun 2011 tentang Pembentukan Peraturan Perundang-undangan. 